\title{
A Multiple Comparison of Service Quality between Public, Foreign Venture and Private Sector Banks in Nepal
}

\author{
Bhanu Pratap Durgapal ${ }^{1}$, Keshav Raj Bhatta ${ }^{2}$ \\ ${ }^{1}$ Department of Commerce, Government Degree College, Someshwar, India) \\ ${ }^{2}$ Department of Commerce, Kailali Multi Campus, Dangadi, Nepal)
}

\begin{abstract}
The present study is aimed at multiple comparisons of service quality between public, foreign venture and private sector banks in Nepal. A sample of three hundred respondents is taken from public, foreign venture and private sector banks which are headquartered in Kathmandu. Factor analysis is employed to uncover the different dimensions of service quality. The service quality dimensions are compared using ANOVA, Kruskal Wallis tests, Tukey's HSD and Dunn's test. The results of the study indicate at a direct competition between foreign banks and private banks. Public sector banks seemed to be perceived low in at least two dimensions of service quality.
\end{abstract}

Keywords- banks, multiple comparison, Nepal, service quality

\section{Introduction}

The basis definition of banking is defined as the business activity of accepting and safeguarding money owned by other individuals and entities, and then lending out this money in order to earn a profit. However this simple activity is no longer going to attract a customer. A customer wants a wide array of services viz. debit and credit cards, providing safe custody of valuable items, lockers, ATM services and online transfer of funds across the country / world. It is probably the effective measurement, management and improvement of service quality which will enable banking institutions to achieve a differential advantage over their competitors (Lewis, 1991). The behavioural implications of service quality offered strong empirical support for the intuitive notion that improving service quality can increase favourable behavioural intentions and decrease unfavourable intentions (Zeithaml \& Berry, 1996).

\subsection{Service quality}

\section{Literature Review}

One of earliest contributors to the concept of service quality was Gronroos (1984) who considered service quality comprising of technical quality, functional quality and corporate image of the organization. $\mathrm{He}$ defined technical quality as what consumer actually receives as a result of his/her interaction with the service firm and is important to him/her and to his/her evaluation of the quality of service. Functional quality dealt with the how part i.e. how a customer gets the technical outcome. The first two components technical and functional quality along with word of mouth publicity, pricing and public relations were supposed to build the third component which was said image. Functional quality was a very important dimension. He concluded these quality dimensions were interrelated.

In another research A. Parasuraman, Valarie A. Zeithaml and Leonard L. Berry, 1985 identified ten dimensions that customers use to form expectations and perceptions about a service. The research also pin pointed four discrepancies or gaps on service provider's side that might affect the customer expectations and perceptions. The researchers later on in the year 1988 developed a scale popularly called SERVQUAL to measure service quality. This scale reduced the number of dimensions form ten to 5 dimensions viz. tangibles, reliability, responsiveness, assurance and empathy. Thus service quality was hypothesized on the basis of gap between customer expectation and customer perceptions.

However Cronin and Taylor (1992) in their research concluded that measurement of service quality through SERVQUAL were based on a flawed paradigm. The researchers found that measurement of service quality based on expectation (what the customers should expect) inconsistent with Woodroof, Cadote and Jenkins who suggested that expectations be based on experience norms - what customers should expect from a service provider given their experience with that specific type of service provider. Thus they suggested that expectation component of the SERVQUAL be dropped and only perception component or performance need to be measured. The service quality should be measured as an attitude. This reduced the original scale from 44 to 22 questions thereby increasing efficiency. The authors also concluded that SERVPERF performed better than SERVQUAL in construct validity. 


\subsection{Service quality in banks}

Singh (2012) in his Ph.D. thesis entitled "Banking Service and Customers satisfaction" found that tangibility was having highest mean score value in foreign banks followed by private banks and public banks. Mean score value of reliability of was found highest in private banks followed by public banks and foreign banks. The mean score value of responsiveness were equal in case of foreign and private banks. The mean score value of assurance was found the highest in private banks followed by public sector banks. The mean score value of empathy was found the highest in foreign banks followed by private banks and public sector banks.

Shrestha (2013) in his study on customers satisfaction in the Nepalese commercial banks found that the average score of customers' responsiveness of foreign joint venture commercial banks were more than the national commercial banks, it means that the customers' of foreign joint venture banks were more satisfied than the customers' of national banks in terms of service provided by Nepalese commercial banks.

Gautam and Dhital (2004) in their research on customer satisfaction in Nepalese commercial banks concluded that customers of joint venture banks were more satisfied than public and private sector banks.

Munusamy,Chelliah and Mun (2010) in their research paper on Service Quality Delivery in the Banking Sector in Malaysia concluded that the combination of assurance, reliability, tangibles, empathy and responsiveness together contributed to $62.1 \%$ effective on customer satisfaction. Haq and Muhammad (2012) in their research compared the public and private sector banks in Pakistan in terms of customer satisfaction. The research concluded that the customers of private sector banks were more satisfied than the customers of public sector banks.

Kumbhar (2011) in his research compared the customer satisfaction of ATM services of public and private sector banks and concluded that the public sector banks needed to improve efficiency, e-fulfillment, easiness \& convenience and perceived value. Likewise, the private sector banks needed to improve easiness and convenience, efficiency, security and responsiveness, brand reputation and perceived value in ATM service.

Koirala and Shrestha (2012) in their research found that of seven commercial banks studied viz. Nepal investment Bank ,Nabil ,Everest Bank, NCC, Prime Commercial Bank, Kist Bank and BOK, the Nepal Investment Bank was the first popular bank and Nabil Bank was second one. Service quality leads to customer relation and brand loyalty and enhances the image of the bank.

Peter Kangis, Vassilis Voukelatos (1997) found that quality expectations and evaluation of services received were marginally higher in the private than in the public sector in most of the dimensions measured; the relative importance attached to each quality attribute was, however, of a similar profile for the two sectors.

In their study (J Bloemer, K De Ruyter, 1998) found that among the service quality dimensions reliability seemed to be the most important factor influencing customer loyalty with banks.

Earlier studies on comparison of public and private sector banks revealed that these studies compared the financial performance of the banks. Non financial parameters as a measure of performance have been given very less attention. In terms of this research gap the present study is an attempt to compare the service quality of public, foreign joint venture and private sector banks in Nepal.

\subsection{Overview of Banks in Nepal}

Our study is based in Kathmandu, the national capital of Nepal. There are a total of 18 banks which have their headquarters in Kathmandu. Off these 18 banks 9 are private banks which are locally owned, 6 are foreign joint venture and 3 are public sector banks. A total of six banks have been selected for the study. The banks are classified on the basis of ownership structure and origin/incorporation. Thus on the above criteria the banks have been categorized into three groups: Public Sector, Foreign Venture and Private Sector. A brief introduction of the banks which form a part of the sample is provided in the next section. Official websites of the different banks are the source of the information presented in the following section.

\section{Public Bank:}

A public sector bank is one in which government owns a major portion of share. The bank is managed and controlled by the government.

\section{Nepal Bank Ltd.}

The first bank of Nepal was established in November 15, 1937. It was formed under the principle of Joint venture (Joint venture between govt. \& general public). Government of Nepal owns 38.60 percent shares and General Public 61.40 percent. (http://www.nepalbank.com.np/bankoverview/introduction.php)

\section{Foreign Joint Venture Bank}

The banks which have their origin and head offices in the foreign country are called foreign banks. Foreign banks are the branches of the banks incorporated abroad. A portion of shares is also held locally (the host country nationals or institutions). They are referred to herein the present study as foreign banks. 
1. Nepal SBI Bank Ltd.: Nepal SBI Bank Ltd. (NSBL) is a subsidiary of State Bank of India (SBI) having 55 percent of ownership. The local partner viz. Employee Provident Fund holds 15\% equity and General Public 30\%. (http://nepalsbi.com.np/content/introduction.cfm)

\section{Standard Chartered Bank of Nepal Limited}

Standard Chartered Bank Nepal Limited has been in operation in Nepal since 1987 when it was initially registered as a joint-venture operation. Today the Bank is an integral part of Standard Chartered Group having an ownership of $75 \%$ in the company with $25 \%$ shares owned by the Nepalese public. (https://www.sc.com/np/about-us/)

\section{Domestic Private Banks}

The banks which are registered and incorporated within the country are called domestic banks. These banks provide financial assistance domestically. Such domestic banks which are owned, managed and controlled by private promoters are referred to as private banks. This group is herein referred to as private banks.

\section{Bank Of Kathmandu Limited}

BOK started its operation in March 1995 with the objective to stimulate the Nepalese economy and take it to newer heights. Bank of Kathmandu Limited (BOK) is entirely managed by Nepalese professionals and owned by the general public. (http://www.bok.com.np/overview/)

\section{Siddhartha Bank Limited (SBL)}

Siddhartha Bank Limited (SBL), established in 2002 and promoted by prominent personalities of Nepal, today stands as one of the consistently growing banks in Nepal. (http://www.siddharthabank.com/About-Us/1/)

\section{Kumari Bank Limited}

Kumari Bank Limited came into existence as the fifteenth commercial bank of Nepal by starting its banking operations from April 03, 2001 with an objective of providing competitive and modern banking services in the Nepalese financial market. $51 \%$ of the paid capital of the bank is contributed from promoters and remaining from public. (www.kumaribank.com/News/welcome-to-kumari-bank.html)

\section{Research Methodology}

3.1 Objectives:

1. To find out if service quality perceptions of customers of public sector, foreign venture and private sector banks differ.

2. To compare the service quality dimensions of public, foreign venture and private sector banks.

\subsection{Hypothesis:}

In the many comparative studies between banks, financial performance is the most widely used parameter studied. However in the present study we studied service quality as a comparative variable. Service quality has been conceptualized as a multi dimensional construct. In line with the previous studies the different dimensions of the service quality as deduced from the present study are named as reliability, assurance, tangibility, empathy, access and responsiveness. The comparison is done by comparing the means of service quality dimensions of public, foreign and private banks. Accordingly the following hypotheses are formulated:

H1: The mean score of reliability dimension of service quality is same between public, foreign venture and private sector banks.

$\mathrm{H} 2$ : The mean score of assurance dimension of service quality is same between public, foreign venture and private sector banks.

H3: The mean score of tangibility dimension of service quality is same between public, foreign venture and private sector banks.

H4: The mean score of empathy dimension of service quality is same between public, foreign venture and private sector banks.

H5: The mean score of accessibility dimension of service quality is same between public, foreign venture and private sector banks.

H6: The mean score of responsiveness dimension of service quality is same between public, foreign venture and private sector banks.

\subsection{Measurement:}

We have used the approach of Servperf scale which is to measure service quality as an attitude. Based on available literature (Cronin and Taylor 1992; Zeithaml et al. 1988) a questionnaire consisting of 27 questions to be measured on a five point likert scale was developed to measure customer perception about service quality of banks. After factor analysis the 27 questions were reduced to 18 and grouped into six factors namely reliability, assurance, tangibility, empathy, access and responsiveness. 
3.4 Study population: The population included all the customers of all the banks which are headquartered in Kathmandu.

\subsection{Sample:}

The study was based in Kathmandu, the Capital of Nepal. There are a total of 18 banks which are headquartered in Kathmandu. Out of a total of 18 banks 9 are private banks, 6 are foreign venture and 3 are public sector banks. Sample size was set at 300. Quota sampling method is used to select the sample. One third banks were to constitute the final sample meaning a total of six banks. Thus based on quota in the first stage 3 private banks, 2 foreign venture and 1 public sector bank were selected. In the second stage from each selected bank 50 customers were sampled on the basis of convenience. This way private bank comprised (3x50) 150 customers, foreign venture (2x50) 100 customers and public sector (1x50) 50 customers.

\subsection{Data collection}

Data was collected in the month of August 2015 by personally visiting the bank premises and getting the self administered questionnaire filled by the respondents.

\subsection{Factor analysis}

\section{Analyses}

Our data contained many variables therefore factor analysis was used to reduce the number of variables. Factor analysis groups variables with similar characteristics together. With factor analysis we produced a small number of factors from a large number of variables which are capable of explaining the observed variance in the larger number of variables. The reduced factors can also be used for further analysis.

\subsubsection{Measures of Appropriateness of Factor Analysis}

Kaiser-Meyer-Olkin (KMO) measures strength of the relationship among variables. The KMO measures the sampling adequacy which should be greater than 0.5 for proceeding to a satisfactory factor analysis. The Kaiser-Meyer-Olkin Measure of Sampling Adequacy (KMO) value of 0.895 indicated that the data is very much suitable for factor analysis (annexure 1.0).

\subsubsection{Principal Component Analysis}

Principal component analysis produced six factors explaining about 61 percent of the variance in the data (annexure 1.1). The first factor explained 34 percent variance. But after rotation the variance in the various factors is evenly distributed. Thus first factor explains 13.5 percent, the second 11.56 , fourth 10 percent and fifth and sixth factors about eight percent. Varimax rotation defined the factor loadings of the various items (annexure 1.2). Small factors having factor loadings less than 0.6 values are considered subservient therefore they are dropped. Thus the six factors with the various items that are retained are presented in figure 1.

\begin{tabular}{|c|c|c|}
\hline \multicolumn{2}{|c|}{ REALIABILITY } & \multirow{2}{*}{$\begin{array}{l}\text { Component coefficient } \\
0.786\end{array}$} \\
\hline 1. & The procedure of Cash deposit and withdrawal is quick and easy & \\
\hline 2. & The Bank provides services to promised. & 0.762 \\
\hline 3. & The Bank performs the services within prescribed time. & 0.665 \\
\hline 4. & The Bank is providing different services at reasonable charges & 0.648 \\
\hline \multicolumn{3}{|c|}{ ASSURANCE } \\
\hline 1. & Bank employees are trustworthy. & 0.777 \\
\hline 2. & The bank is providing proper safety and security of deposits. & 0.764 \\
\hline \multicolumn{3}{|c|}{ TANGIBILITY } \\
\hline 1. & Waiting room, toilet facility, water facilities, etc for the customers are satisfactory. & 0.811 \\
\hline 2. & The bank has its own parking facility. & 0.808 \\
\hline 3. & The interior of the bank is very impressive. & 0.624 \\
\hline \multicolumn{3}{|c|}{ EMPATHY } \\
\hline 1. & The employees of the bank are friendly and polite. & 0.673 \\
\hline 2. & The behaviour of employees at reception desk is inappropriate. & 0.660 \\
\hline 3. & The employees of the bank know the needs of their customers. & 0.652 \\
\hline \multicolumn{3}{|c|}{ RESPONSIVENESS } \\
\hline 1. & The Bank provides free financial counselling services. & 0.781 \\
\hline 2. & There is an enquiry desk facility at the bank. & 0.644 \\
\hline 3. & The bank is providing modern technological facilities to its customers. & 0.644 \\
\hline 4. & The Bank provides SMS banking facility. & 0.610 \\
\hline & ILITY & \\
\hline
\end{tabular}




\begin{tabular}{|ll|l|}
\hline 1. & ATM booths of the bank are at the convenient places & 0.737 \\
\hline 2. & The Bank branches are at the convenient places & 0.760 \\
\hline
\end{tabular}

Figure 1.0: Factors extracted along with items after factor analysis

\subsection{Reliability analysis}

The scale formed by combining similar items and groupings resulted into six factors: service quality dimensions. Each of the scales representing different dimensions is checked for internal consistency by Reliability analysis by calculating the value of Cronbach's alpha. Our analyses showed fairly good values of alpha thus it can be said the internal consistency of the scale is good in case of reliability, tangibility and empathy scales and acceptable in case of assurance, responsiveness and accessibility scales (Annexure 2.0). Therefore it can be said that the scales are measuring the construct as intended.

\subsection{Comparison of Service quality dimensions of three bank groups:}

The best way to compare the means is to use ANOVA. But before conducting ANOVA it is important to assure the data set meets the ANOVA assumptions which are:

1. Independence of observations.

2. Normality - the distribution of the variable should be normal

3. Homogeneity of variance - Equal variances between groups.

The first assumption is met because samples taken from three groups of banks are independent. Then each dimension of service quality is checked for ANOVA assumption: normality and homogeneity of test.

\subsubsection{Data Testing for Normality:}

An assessment of the normality of data is a prerequisite for many statistical tests as normal data is an underlying assumption in parametric testing. In this study the Kolmogorov-Smirnov test (K-S test) is used for checking the normality. The result indicates that the null hypothesis: the data are normally distributed for all variables (reliability, assurance, tangibility, empathy, access and responsiveness) are rejected at 0.05 significance level (annexure 3.0). ANOVA is robust to violation of normality test. Therefore we may continue with the parametric test but before that another assumption of ANOVA is homogeneity of variance (HOV). It tests whether the variances in the groups are same or significantly different. Levene test is used to test HOV. The results of Lavene test revealed that Reliability, Assurance and Tangibility dimensions show equal variances between groups. (Annexure 4.1, 4.2, 4.3) Therefore for these dimensions we continue with ANOVA.

\subsubsection{Comparing means of reliability, assurance and tangibility dimensions of service quality between groups of banks}

The result of ANOVA rejected the first hypothesis (H1) (annexure 5.1). Therefore we conclude that there is significant difference in reliability dimension of service quality between public, foreign venture and private sector banks.

The result of ANOVA accepted the second hypothesis (H2) (annexure 6.0). Therefore we conclude that there is no significant difference in assurance dimension of service quality between public, foreign venture and private sector banks. The three groups of banks are perceived same in assurance dimension of service quality.

Likewise the result of ANOVA accepted the third hypothesis (H3) (annexure 7.0). Therefore we conclude that there is no significant difference in tangibility dimension of service quality between public, foreign venture and private sector banks. The three groups of banks are perceived same in tangibility dimension of service quality.

\subsubsection{Comparing means for Empathy, Access and Responsiveness dimensions of service quality between groups of banks:}

For the remaining three dimensions empathy, access and responsiveness the Lavene test result accepts the null hypothesis: unequal variances across all groups (annexure 4.4, 4.5, 4.6). ANOVA is robust to this violation when the groups are of equal or near equal size; however, our data set consists of unequal sample sizes therefore we cannot proceed with one-way analysis of variance. Non parametric tests are not affected by these violations. The non parametric equivalent of ANOVA is known as Kruskal Wallis test. Thus for comparing the means of empathy, access and responsiveness dimensions of service quality between public, foreign and private banks Kruskal Wallis test is used.

The results of Kruskal Wallis tests rejected the fourth, fifth and sixth hypothesis (H4, H5, H6). (Annexure 8.0)Therefore we conclude that there are significant differences in empathy, access and responsiveness dimensions of service quality between public, foreign venture and private sector banks. 


\subsubsection{All pair wise comparison of means of service quality dimensions}

The above analyses have been helpful in ascertaining the dimensions of service quality in which banks differ; we know that there are significant differences in reliability, empathy, access and responsiveness dimensions of service quality between public, foreign venture and private sector banks. But the above analysis did not tell which banks differ i.e. whether all three banks are perceived differently or the difference is between any two banks. The answer is running post hoc analyses which are pair wise comparison and is discussed next.

\subsubsection{Pair wise comparison of the means of reliability dimension of service quality}

For those dimensions in which ANOVA was used for comparison the post hoc analyses is done using Tukey's HSD. Because assurance and tangibility dimensions did not show significant difference among groups of banks therefore post hoc is done only for reliability dimension. Tukey's HSD clarified that among the three banks; honestly significant difference exists only between foreign venture and private sector banks (annexure 5.0)

\subsubsection{Pair wise comparison of the means of empathy, access and responsiveness dimensions}

Similarly post hoc analysis of Kurskal Wallis test is done using Dunn's test to determine which groups in the sample differ. Thus pair wise comparison between the different group's revealed significant difference between public versus foreign venture banks, and public versus private sector banks in case of empathy and responsiveness dimensions. In case of access dimension there is significant difference between foreign venture versus private, and private versus public sector banks.

\section{Discussion}

From factor analysis it is clear that the variables affecting the service quality can be reduced to smaller numbers and grouped into six factors. In line with the previous studies Parasuraman et al. (1988) the six factors were characterized as reliability, assurance, tangibility, empathy, access and responsiveness. Each of these dimensions of service quality was compared between foreign, private and public sector banks. A multiple comparison of six dimensions between groups of banks resulted in determining that four of the dimensions of service quality: reliability, empathy, access and responsiveness differed between groups of banks. The two dimensions: assurance and tangibility did not show significant differences between groups of banks. Thus it could be said that customers perceived service quality of foreign, private and public sector banks different on reliability, empathy, access and responsiveness variables/dimensions. To substantiate the service quality perception differences between foreign, private and public sector banks post hoc analyses was performed. In post hoc analyses pair wise comparison is done between the three pair i.e. Foreign venture V/s Public, Foreign venture V/s Private and Public V/s Private. The results of post hoc analyses are summarized in the next section.

\subsection{Summarizing the discussion}

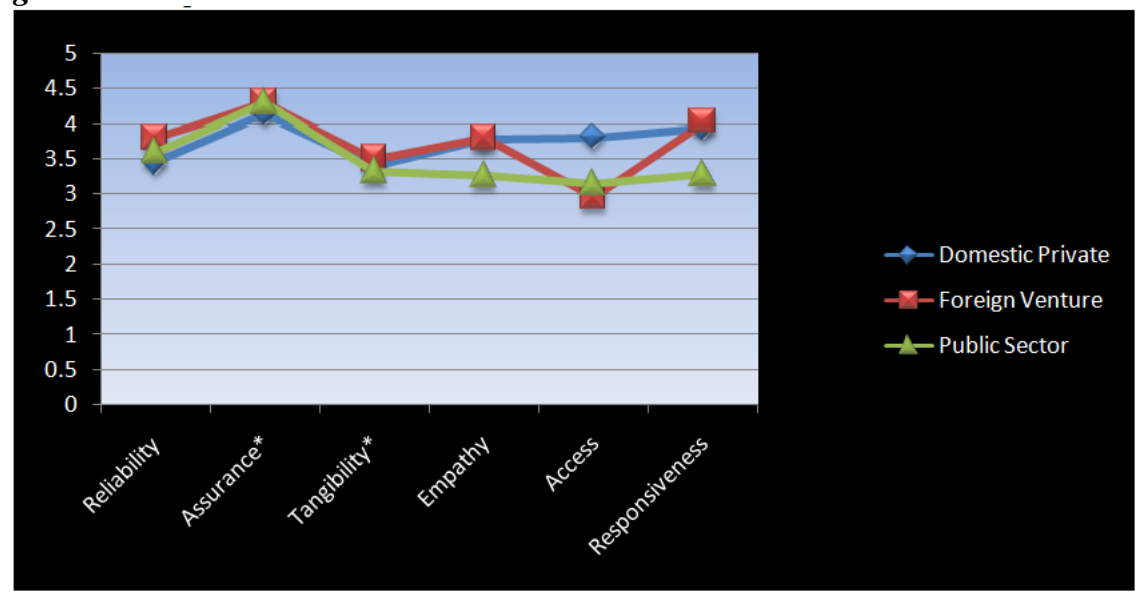

\subsubsection{Foreign venture banks Vs Private Banks}

Pair wise comparison revealed significant difference between reliability dimensions; the foreign venture got higher score on this dimension. Significant difference was also found in access dimension. Customer perceived private banks more approachable.

\subsubsection{Foreign venture Vs Public sector Banks}

Significant difference was found in empathy and responsiveness dimensions. Foreign venture banks got higher rating than public sector banks in both the dimensions. No significant difference was found in reliability dimension. 


\subsubsection{Private Vs Public sector Banks}

Significant difference found in empathy, access and responsiveness dimensions of the service quality between private and public sector banks. In all three dimensions private sector banks received a higher rating than public sector banks.

A measure of difference at the individual dimension is provided in the following section.

i) Reliability: The difference between customers' perception against the attributes of this dimension varies significantly between the foreign and private banks. This may imply that customers feel the foreign venture banks have better ability to perform the promised services dependably and accurately when compared to private banks. A direct comparison of foreign and public sector banks did not reveal significant difference in this dimension.

ii) Empathy: Customers perceived that the staff of foreign venture banks as more polite and friendly than public sector. Similarly private sector banks are perceived better than public sector banks in empathy.(Annexure 8.1)

iii) Accessibility: As far as location convenience the customers of private banks believed that the branches are easily accessible compared to public sector and foreign venture banks.(Annexure 8.2)

iv) Responsiveness: There is statistically significant difference in this service quality dimension between foreign $\mathrm{v} / \mathrm{s}$ public and private $\mathrm{v} / \mathrm{s}$ public sector banks. In direct comparison the Nepalese customers' perceive that employees in the foreign venture banks exhibit higher willingness to help customers and provide prompt service than public sector bank employees. Similarly pair wise comparison of private sector banks with public sector banks also revealed better performance of private sector banks. (Annexure 8.3)

Assurance and tangibility dimensions did not show difference between different groups of banks. That means that assurance and tangibility service quality dimension are not a differentiating factor among the customers of banks in Nepal.

\section{Conclusion}

Factor analysis resulted in producing six factors which were named as reliability, assurance, tangibility, empathy, access and responsiveness. These factors were further analysed by comparing their mean between foreign, private and public sector banks which lead to identification of four of the six dimensions viz. reliability, empathy, access and responsiveness which can be said to be service quality variables which differentiate the public, foreign venture and private banks. These service quality dimensions are perceived differently by the customers. The significance of difference was substantiated in post hoc analyses where the three groups were paired into three sets and compared with each other. The result pointed at direct competition between foreign venture and private sector. In post hoc analyses pair wise comparison is done between the three pair i.e. Foreign venture Vs Public, Foreign venture Vs Private and Public V/s Private. The post hoc analysis revealed honestly significant difference between foreign venture and domestic private banks when compared on reliability dimension of service quality. Empathy and responsiveness dimensions were perceived differently in direct comparison between the customers of Foreign venture and Public sector banks. In direct comparison between Foreign venture and Private sector banks significant difference was noticed in access dimension of service quality. The other two dimensions viz. tangibility and assurance did not show any significant difference between the public, foreign venture and private banks. Thus we can conclude that the public, foreign venture and private banks in Nepal are perceived differently on the reliability, empathy, access and responsiveness dimensions of service quality. Foreign venture banks are perceived better in reliability dimension of service quality. The customers feel the bank can perform the promised services effectively. Private Banks are perceived to be more approachable. The customers perceived the locations of branches and ATMs conveniently located. Public sector banks in direct comparison with Foreign venture and Private sector banks separately scored lowest in empathy and responsiveness dimensions of service quality. In case of reliability dimension no significant difference was found between foreign and public. Similarly in case of access dimension significant difference between foreign and public sector banks indicated that in terms of convenience of location public sector banks fared better than foreign venture banks.

The foreign banks scored minimum in accessibility dimension of service quality that indicates that these banks can improve their approachability by opening new branches and ATMs in the country. Private sector banks are perceived high on access dimension in comparison to other foreign venture and public sector banks. But in terms of one important dimension in banking industry: reliability, the private banks have still to win the hearts of the customers. The plausible reasons for lagging in this crucial dimension could be being new entrants therefore lacking needed experience. Annual survey by public relations firm Edelman opined that the concepts of trust and reputations are inseparable. A financial institution's reputation (i.e., its brand) is a consumer's aggregate feelings about its past behaviours. Past performance creates future expectations, which in turn determines the degree of 
trust a consumer places in an organization. Private Banks being new in the market do not have a brand value. Lastly in comparison to foreign venture and private banks the public sector banks are perceived low in empathy, responsiveness dimensions. The respondents did not consider the staff as polite and not providing prompt service to their requirements. The public sector bank staffs need to be more polite and friendly with their customers and also active in promptly serving the customer needs. The bank should also open new branches.

The study is crucial for a developing economy like Nepal where banks play a key role. Public sector banks need to realize that banking is not only limited to transaction of money but a number of aspects are relevant for marketing. Accordingly the employees of these banks should be given training on customer service management. Private sector banks should create advertisements which highlight the reliability of their services, while foreign venture banks should focus on increasing accessibility to customers.

The only limitation of the study is sampling. Non probability method of sampling is employed. Therefore the data collected may not be accurate representative of the population.

\section{References}

[1]. Barbara R. Lewis (1991). Service quality: An international comparison of bank customers' expectations and perceptions. Journal of Marketing Management.

[2]. Christian Gronroos, (1984). A Service Quality Model and its Marketing Implications, European Journal of Marketing, Vol. 18 Iss: 4 , pp.36- 44 .

[3]. Gautam,T.and Dhital,S. (2004).Customer Satisfaction in Nepalese Commercial Banks, Journal of Management and Development Review, Pp.1-18.

[4]. Haq,W.U. and Muhammad,B.(2012).Customer Satisfaction :A Comparison of Public and Private Banks of Pakistan. IOSR Journal of Business and Management (IOSRJBM), ISSN; 2278-487X,1(5),July-Aug.,pp.1-5.

[5]. J Bloemer, K De Ruyte (1998).Investigating drivers of bank loyalty: the complex relationship between image, service quality and satisfaction. International Journal of Bank Marketing.

[6]. J. Joseph Cronin, Jr. and Steven A.Taylor (1994). SERVPERF versus SERVQUAL: Reconciling Performance-Based and Perceptions-Minus-Expectations Measurement of Service Quality. Vol. 58, No. 1 (Jan 1994), pp. 125-131.

[7]. Kumbhar,V.M.(2011).Customers' Satisfaction in ATM Service: An Empirical Evidences from Public and Private sector Banks in India. Management research and Practice, 3(2), June, pp.24-35

[8]. Munusamy,J.,Chelliah,S.and Mun,H. W.(2010).Service Quality Delivery and its Impact on Customer Satisfaction in the Banking Sector in Malaysia.International Journal of Innovation,Management and Technology,ISSN:2010-0248,Vol.1,No.4,October,pp.398404.

[9]. Parasuraman A.,Zeithaml,V.A.,and Berry L.L(1988). "SERVQUAL": A multi- item scale for measuring consumers perceptions of the service quality". Journal of Reliability,Vol. 64,No. 1,pp.12-40.

[10]. Peter Kangis, Vassilis Voukelatos (1997) "Private and public banks: a comparison of customer expectations and perceptions", International Journal of Bank Marketing, Vol. 15 Iss: 7, pp. $279-287$

[11]. RB Woodruff, ER Cadotte(1983), RL Jenkins (1983). Modelling consumer satisfaction processes using experience-based norms. Journal of marketing research.

[12]. Shrestha,S.K.(2013) . An empirical study of customers' satisfaction in the Nepalese commercial banks. The Nepalese Management Review,XVI(1), July Pp.30-35

[13]. Singh, Surabhi (2012). Banking Service and Customer Satisfaction, Ph.D. Thesis submitted to University of Delhi.

[14]. http://nepalsbi.com.np/content/introduction.cfm. (n.d.). Retrieved October 2015, 2015, from www.nepalsbi.com.np: http://www.nepalsbi.com.np/

[15]. http://www.bok.com.np/overview/. (n.d.). Retrieved october 16, 2015, from www.bok.com.np: http://www.bok.com.np/

[16]. http://www.nepalbank.com.np/bankoverview/introduction.php. (n.d.). Retrieved october 16, 2015, from www.nepalbank.com: http://www.nepalbank.com.np/

[17]. http://www.siddharthabank.com/About-Us/1/. (n.d.). Retrieved October 16, 2015, from www.siddharthabank.com: http://www.siddharthabank.com

[18]. https://www.sc.com/np/about-us/. (n.d.). Retrieved october 16, 2015, from www.sc.com/np: https://www.sc.com/np/

[19]. www.kumaribank.com/News/welcome-to-kumari-bank.html. (n.d.). Retrieved october 16, 2015, from www.kumaribank.com: http://www.kumaribank.com

[20]. Valarie A. Zeithaml, Leonard L Berry (1996). The Behavioural Consequences of Service Quality. Journal of Marketing

\section{Annexure}

Annexure 1.0: KMO and Bartlett's Test

\begin{tabular}{|l|l|l|}
\hline \multicolumn{2}{|l|}{ Kaiser-Meyer-Olkin Measure of Sampling Adequacy. } & .895 \\
\hline \multirow{3}{*}{ Bartlett's Test of Sphericity } & Approx. Chi-Square & 3896.029 \\
\cline { 2 - 3 } & df & 351 \\
\cline { 2 - 3 } & & .000 \\
\cline { 2 - 3 } & Sig. & \\
\hline
\end{tabular}

\begin{tabular}{|c|c|c|c|c|c|c|c|c|c|}
\hline \multicolumn{10}{|c|}{ Annexure 1.1: Total Variance Explained } \\
\hline \multirow[t]{2}{*}{ Component } & \multicolumn{3}{|c|}{ Initial Eigenvalues } & \multicolumn{3}{|c|}{ Extraction Sums of Squared Loadings } & \multicolumn{3}{|c|}{ Rotation Sums of Squared Loadings } \\
\hline & Total & $\%$ of Variance & $\begin{array}{l}\text { Cumulative } \\
\%\end{array}$ & Total & $\begin{array}{l}\% \text { of } \\
\text { Variance }\end{array}$ & Cumulative $\%$ & Total & $\begin{array}{l}\% \text { of } \\
\text { Variance }\end{array}$ & Cumulative \% \\
\hline 1 & 9.216 & 34.135 & 34.135 & 9.216 & 34.135 & 34.135 & 3.671 & 13.595 & 13.595 \\
\hline 2 & 2.174 & 8.051 & 42.186 & 2.174 & 8.051 & 42.186 & 3.120 & 11.556 & 25.151 \\
\hline 3 & 1.837 & 6.805 & 48.991 & 1.837 & 6.805 & 48.991 & 2.945 & 10.908 & 36.059 \\
\hline 4 & 1.305 & 4.834 & 53.824 & 1.305 & 4.834 & 53.824 & 2.470 & 9.148 & 45.207 \\
\hline 5 & 1.162 & 4.305 & 58.129 & 1.162 & 4.305 & 58.129 & 2.268 & 8.398 & 53.605 \\
\hline
\end{tabular}


A Multiple Comparison of Service Quality between Public, Foreign Venture and Private Sector .....

\begin{tabular}{|c|c|c|c|c|c|c|c|c|c|}
\hline 6 & 1.038 & 3.846 & 61.975 & 1.038 & 3.846 & 61.975 & 2.260 & 8.370 & 61.975 \\
\hline 7 & .979 & 3.627 & 65.602 & & & & & & \\
\hline 8 & .890 & 3.297 & 68.899 & & & & & & \\
\hline 9 & .837 & 3.100 & 71.999 & & & & & & \\
\hline 10 & .779 & 2.885 & 74.884 & & & & & & \\
\hline 11 & .720 & 2.665 & 77.549 & & & & & & \\
\hline 12 & .626 & 2.318 & 79.867 & & & & & & \\
\hline 13 & .588 & 2.177 & 82.044 & & & & & & \\
\hline 14 & .551 & 2.040 & 84.083 & & & & & & \\
\hline 15 & .515 & 1.906 & 85.989 & & & & & & \\
\hline 16 & .491 & 1.818 & 87.807 & & & & & & \\
\hline 17 & .447 & 1.656 & 89.463 & & & & & & \\
\hline 18 & .406 & 1.502 & 90.966 & & & & & & \\
\hline 19 & .368 & 1.362 & 92.327 & & & & & & \\
\hline 20 & .340 & 1.259 & 93.586 & & & & & & \\
\hline 21 & .307 & 1.138 & 94.724 & & & & & & \\
\hline 22 & .295 & 1.092 & 95.816 & & & & & & \\
\hline 23 & .261 & .967 & 96.783 & & & & & & \\
\hline 24 & .246 & .910 & 97.693 & & & & & & \\
\hline 25 & .238 & .881 & 98.574 & & & & & & \\
\hline 26 & .196 & .725 & 99.299 & & & & & & \\
\hline 27 & .189 & .701 & 100.000 & & & & & & \\
\hline
\end{tabular}

\begin{tabular}{|c|c|c|c|c|c|c|}
\hline \multicolumn{7}{|l|}{ Annexure 1.2: Rotated Component Matrix ${ }^{\mathrm{a}}$} \\
\hline & \multicolumn{6}{|c|}{ Component } \\
\hline & 1 & 2 & 3 & 4 & 5 & 6 \\
\hline \multicolumn{7}{|l|}{ 1. The accounts opening procedure is simple and easy } \\
\hline 2. The procedure of cash deposit and withdrawal is quick and easy. & .786 & & & & & \\
\hline 3. The Bank provides services as promised. & .762 & & & & & \\
\hline \multicolumn{7}{|l|}{ 4. There is a proper queue system in the cash counter. } \\
\hline 5. The Bank performs the services within the prescribed standard time & .665 & & & & & \\
\hline \multicolumn{7}{|l|}{ 6. The Bank has good reputation in the banking industry. } \\
\hline 7. The Bank is providing different services at reasonable charges. & .648 & & & & & \\
\hline \multicolumn{7}{|l|}{ 8. The products of the bank are popular } \\
\hline \multicolumn{7}{|l|}{ 9. The Bank provides account statement when required. } \\
\hline 10. The customers feel bank employees to be trustworthy. & & & & & & .777 \\
\hline 11. The bank is providing proper safety and security of deposits. & & & & & & .764 \\
\hline \multicolumn{7}{|l|}{ 12. The bank maintains complaint box properly at the branch. } \\
\hline \multicolumn{7}{|l|}{ 13. The skill and knowledge of the bank employees are satisfactory } \\
\hline \multicolumn{7}{|l|}{ 14. The interest rate on deposit is attractive. } \\
\hline 15. The bank is providing modern technology facilities to its customers. & & & .644 & & & \\
\hline 16. ATM booths of the bank are at the convenient places.' & & & & & .737 & \\
\hline 17. The bank branches are at the convenient places. & & & & & .760 & \\
\hline 18. The Bank has its own parking facility. & & .808 & & & & \\
\hline 19. Waiting room, toilet facility, water facilities, etc for the customers are satisfactory & & .811 & & & & \\
\hline 20. The interior of the bank is very impressive & & .624 & & & & \\
\hline 21. The employees of the bank are friendly and polite. & & & & .673 & & \\
\hline 22. The behavior of the employees at reception desk is appreciable. & & & & .660 & & \\
\hline 23. The employees of the bank know the needs of their customers. & & & & .652 & & \\
\hline \multicolumn{7}{|l|}{ 24. Customers' grievances are settled immediately. } \\
\hline 25. The bank provides SMS banking facility. & & & .781 & & & \\
\hline 26. The bank provides free counselling services. & & & .644 & & & \\
\hline 27. There is an enquiry desk facility at the bank. & & & .610 & & & \\
\hline \multicolumn{7}{|l|}{ Extraction Method: Principal Component Analysis. } \\
\hline
\end{tabular}

Annexure 2.0: Reliability test

\begin{tabular}{|c|l|l|l|}
\hline & Service Quality dimension & Cranach's Alpha & Number of Items \\
\hline 1. & Reliability & .821 & 4 \\
\hline 2. & Assurance & .781 & 2 \\
\hline 3. & Tangibility & .802 & 3 \\
\hline 4. & Empathy & .871 & 3 \\
\hline 5. & Responsiveness & .734 & 4 \\
\hline 6. & Accessibility & .790 & 2 \\
\hline
\end{tabular}

\begin{tabular}{|l|l|l|l|l|l|l|}
\hline \multicolumn{7}{|c|}{ Annexure 3.0 : Tests of Normality } \\
\hline & Kolmogorov-Smirnov & \multicolumn{2}{l|}{ Shapiro-Wilk } \\
\cline { 2 - 7 } & Statistic & df & Sig. & Statistic & df & Sig. \\
\hline
\end{tabular}


A Multiple Comparison of Service Quality between Public, Foreign Venture and Private Sector .....

\begin{tabular}{|l|l|l|l|l|l|l|}
\hline RELVAL & .136 & 300 & .000 & .971 & 300 & .000 \\
\hline ASSURVAL & .252 & 300 & .000 & .838 & 300 & .000 \\
\hline TANGVAL & .149 & 300 & .000 & .958 & 300 & .000 \\
\hline EMPATHYVAL & .173 & 300 & .000 & .928 & 300 & .000 \\
\hline ACCESSVAL & .235 & 300 & .000 & .919 & 300 & .000 \\
\hline RESPONSVAL & .131 & 300 & .000 & .950 & 300 & .000 \\
\hline
\end{tabular}

\begin{tabular}{|c|c|c|c|}
\hline \multicolumn{4}{|c|}{ Annexure 4.1: Test of Homogeneity of Variances } \\
\hline \multicolumn{4}{|c|}{ RELVAL } \\
\hline Levene Statistic & df1 & df2 & Sig. \\
\hline 1.662 & 2 & 297 & .192 \\
\hline
\end{tabular}

\begin{tabular}{|c|c|c|c|}
\hline \multicolumn{4}{|c|}{ Annexure 4.2: Test of Homogeneity of Variances } \\
\hline \multicolumn{4}{|l|}{ ASSURANCE } \\
\hline Levene Statistic & df1 & df2 & Sig. \\
\hline 2.385 & 2 & 297 & .094 \\
\hline
\end{tabular}

\begin{tabular}{|c|c|c|c|}
\hline \multicolumn{4}{|c|}{ Annexure 4.3: Test of Homogeneity of Variances } \\
\hline \multicolumn{4}{|c|}{ TANGIBILITY } \\
\hline Levene Statistic & df1 & df2 & Sig. \\
\hline 2.310 & 2 & 297 & .101 \\
\hline
\end{tabular}

\begin{tabular}{|c|c|c|c|}
\hline \multicolumn{4}{|c|}{$\begin{array}{l}\text { Annexure } 4.4 \text { : Test of Homogeneity of Variances } \\
\text { EMPATHY }\end{array}$} \\
\hline Levene Statistic & df1 & df2 & Sig. \\
\hline 5.705 & 2 & 297 & .004 \\
\hline
\end{tabular}

\begin{tabular}{|c|c|c|c|}
\hline \multirow{2}{*}{\multicolumn{4}{|c|}{$\begin{array}{l}\text { Annexure 4.5: Test of Homogeneity of Variances } \\
\text { ACCESS }\end{array}$}} \\
\hline & & & \\
\hline Levene Statistic & df1 & df2 & Sig. \\
\hline 10.193 & 2 & 297 & .000 \\
\hline
\end{tabular}

\begin{tabular}{|c|c|c|c|}
\hline \multirow{2}{*}{\multicolumn{4}{|c|}{ Annexure 4.6: Test of Homogeneity of Variances }} \\
\hline & & & \\
\hline Levene Statistic & df1 & $\mathrm{df} 2$ & Sig. \\
\hline 6.434 & 2 & 297 & .002 \\
\hline
\end{tabular}

\begin{tabular}{|l|l|l|l|l|l|}
\hline \multicolumn{7}{|c|}{ Annexure 5.1 : ANOVA } \\
\hline RELVAL & Sum of Squares & Df & Mean Square & F & Sig. \\
\hline & 7.431 & 2 & 3.715 & 6.835 & .001 \\
\hline Between Groups & 161.441 & 297 & .544 & & \\
\hline Within Groups & 168.872 & 299 & & & \\
\hline Total &
\end{tabular}

\begin{tabular}{|c|c|c|c|c|c|c|}
\hline \multicolumn{7}{|c|}{ Annexure 5.0 : Multiple Comparisons } \\
\hline \multicolumn{7}{|c|}{$\begin{array}{l}\text { Dependent Variable: RELVAL } \\
\text { Tukey HSD }\end{array}$} \\
\hline \multirow[t]{2}{*}{ (I) BANKTYPE } & \multirow[t]{2}{*}{ (J) BANKTYPE } & \multirow{2}{*}{ Mean Difference (I-J) } & \multirow[t]{2}{*}{ Std. Error } & \multirow[t]{2}{*}{ Sig. } & \multicolumn{2}{|c|}{$95 \%$ Confidence Interval } \\
\hline & & & & & Lower Bound & Upper Bound \\
\hline \multirow[t]{2}{*}{ PUBLIC } & FOREIGN & -.19500 & .12770 & .280 & -.4958 & .1058 \\
\hline & PRIVATE & .15667 & .12040 & .396 & -.1269 & .4403 \\
\hline \multirow[t]{2}{*}{ FOREIGN } & PUBLIC & .19500 & .12770 & .280 & -.1058 & .4958 \\
\hline & PRIVATE & $.35167^{*}$ & .09518 & .001 & .1275 & .5759 \\
\hline \multirow{2}{*}{ PRIVATE } & PUBLIC & -.15667 & .12040 & .396 & -.4403 & .1269 \\
\hline & FOREIGN & $-.35167^{*}$ & .09518 & .001 & -.5759 & -.1275 \\
\hline
\end{tabular}

\begin{tabular}{|l|l|l|l|l|l|}
\hline \multicolumn{7}{|c|}{ Annexure 6.0: ANOVA } \\
\hline ASSURANCE & Sum of Squares & Df & Mean Square & F & Sig. \\
\hline Between Groups & 1.691 & 2 & .845 & 2.604 & .076 \\
\hline Within Groups & 96.418 & 297 & .325 & & \\
\hline Total & 98.109 & 299 & & & \\
\hline
\end{tabular}

\begin{tabular}{|l|l|l|l|l|l|}
\hline \multicolumn{7}{|c|}{ Annexure 7.0: ANOVA } \\
\hline TANGIBILITY & Sum of Squares & Df & Mean Square & F & Sig. \\
\hline Between Groups & 1.177 & 2 & .588 & .725 & .485 \\
\hline
\end{tabular}


A Multiple Comparison of Service Quality between Public, Foreign Venture and Private Sector .....

\begin{tabular}{|l|l|l|l|l|l|}
\hline Within Groups & 241.126 & 297 & .812 & & \\
\hline Total & 242.302 & 299 & & & \\
\hline
\end{tabular}

Annexure 8.0

Hypothesis Test Summary

\begin{tabular}{|c|c|c|c|c|}
\hline & Null Hypothesis & Test & Sig. & Decision \\
\hline 1 & $\begin{array}{l}\text { The distribution of EMPATHY is th } \\
\text { same across categories of } \\
\text { BANKTYPE. }\end{array}$ & $\begin{array}{l}\text { Jndependent- } \\
\text { Kamples } \\
\text { Kruskal- } \\
\text { Wallis Test }\end{array}$ & .001 & $\begin{array}{l}\text { Reject the } \\
\text { null } \\
\text { hypothesis. }\end{array}$ \\
\hline 2 & $\begin{array}{l}\text { The distribution of ACCESS is the } \\
\text { same across categories of } \\
\text { BANKTYPE. }\end{array}$ & $\begin{array}{l}\text { Independent- } \\
\text { Samples } \\
\text { Kruskal- } \\
\text { Wallis Test }\end{array}$ & .000 & $\begin{array}{l}\text { Reject the } \\
\text { null } \\
\text { hypothesis. }\end{array}$ \\
\hline 3 & $\begin{array}{l}\text { The distribution of RESPONSE is } \\
\text { the same across categories of } \\
\text { BANKTYPE. }\end{array}$ & $\begin{array}{l}\text { Independent- } \\
\text { Samples } \\
\text { Kruskal- } \\
\text { Wallis Test }\end{array}$ & .000 & $\begin{array}{l}\text { Reject the } \\
\text { null } \\
\text { hypothesis. }\end{array}$ \\
\hline
\end{tabular}

Asymptotic significances are displayed. The significance level is .05 .

Annexure 8.1

\section{Pairwise Comparisons of TYPEOFBANK}

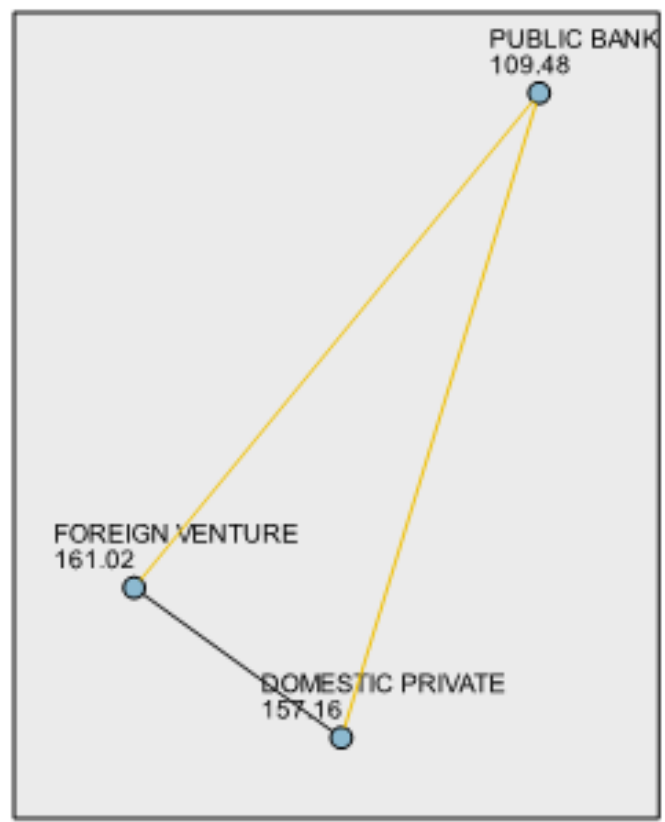

Each node shows the sample average rank of TYPEOFBANK.

\begin{tabular}{|c|c|c|c|c|c|}
\hline Sample1-Sample2 & $\begin{array}{c}\text { Test } \\
\text { Statistic } \\
\end{array}$ & $\begin{array}{l}\text { Std. } \\
\text { Error }\end{array}$ & $\begin{array}{l}\text { Std. Test } \\
\text { Statistic }\end{array}$ & Sig. & Adj.Sig. \\
\hline $\begin{array}{l}\text { PUBLIC BANK-DOMESTIC } \\
\text { PRIVATE }\end{array}$ & -47.680 & 13.860 & -3.440 & .001 & .002 \\
\hline $\begin{array}{l}\text { PUBLIC BANK-FOREIGN } \\
\text { VENTURE }\end{array}$ & -51.540 & 14.701 & -3.506 & .000 & .001 \\
\hline $\begin{array}{l}\text { DOMESTIC PRIVATE-FOREIGN } \\
\text { VENTURE }\end{array}$ & 3.860 & 10.958 & .352 & .725 & 1.000 \\
\hline
\end{tabular}

Each row tests the null hypothesis that the Sample 1 and Sample 2 distributions are the same.

Asymptotic significances (2-sided tests) are displayed. The significance level is ,05. 
Annexure 8.2

Pairwise Comparisons of TYPEOFBANK

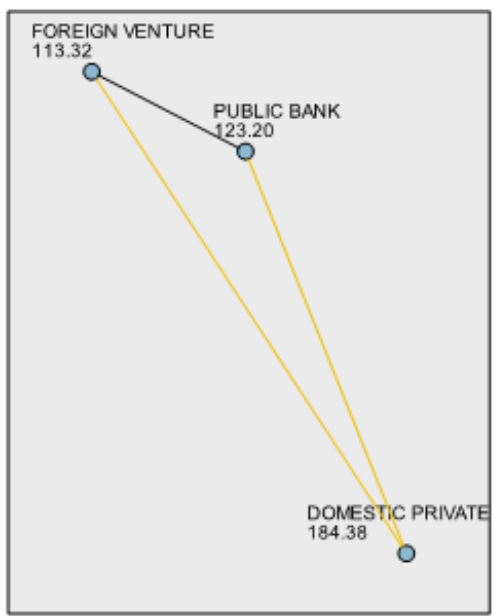

Each node shows the sample average rank of TYPEOFBANK.

\begin{tabular}{|lrrrrr|}
\hline Sample1-Sample2 & $\begin{array}{c}\text { Test } \\
\text { Statistic }\end{array}$ & $\begin{array}{c}\text { Std. } \\
\text { Error }\end{array}$ & $\begin{array}{c}\text { Std. Test } \\
\text { Statistic }\end{array}$ & Sig. & Adj.Sig. \\
\cline { 2 - 6 } $\begin{array}{l}\text { FOREIGN VENTURE-PUBLIC } \\
\text { BANK }\end{array}$ & 9.875 & 14.529 & .680 & .497 & 1.000 \\
\hline $\begin{array}{l}\text { FOREIGN VENTURE-DOMESTIC } \\
\text { PRIVATE }\end{array}$ & -71.058 & 10.830 & -6.561 & .000 & .000 \\
\hline $\begin{array}{l}\text { PUBLIC BANK-DOMESTIC } \\
\text { PRIVATE }\end{array}$ & -61.183 & 13.699 & -4.466 & .000 & .000 \\
\hline
\end{tabular}

Each row tests the null hypothesis that the Sample 1 and Sample 2 distributions are the same.
Asymptotic significances (2-sided tests) are displayed. The significance level is .05,

Annexure 8.3

Pairwise Comparisons of TYPEOFBANK

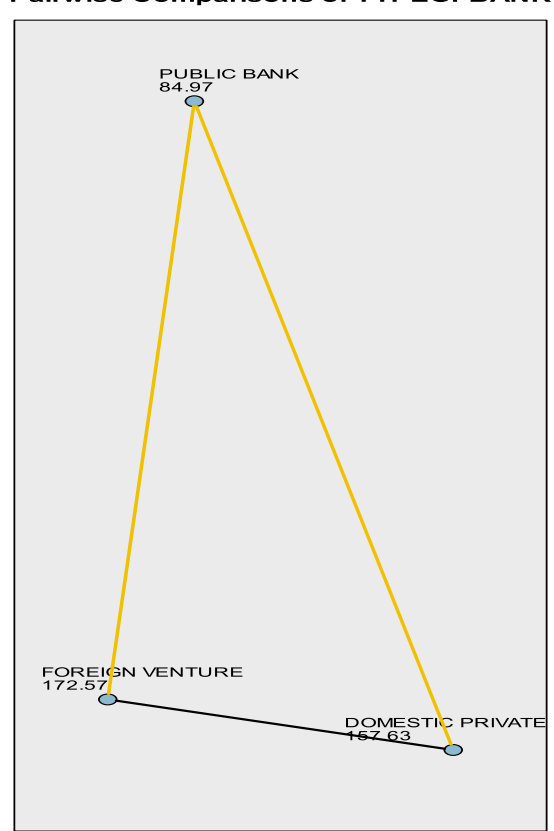

Each node shows the sample average rank of TYPEOFBANK

\begin{tabular}{|lrcccc|}
\hline Sample1-Sample 2 & $\begin{array}{c}\text { Test } \\
\text { Statistic }\end{array}$ & $\begin{array}{c}\text { Std. } \\
\text { Error }\end{array}$ & $\begin{array}{c}\text { Std. Test } \\
\text { Statistic }\end{array}$ & \multicolumn{1}{c|}{ Sig. } & \multicolumn{1}{c|}{ Adj.Sig. } \\
\hline $\begin{array}{l}\text { PUBLIC BANK-DOMESTIC } \\
\text { PRIVATE }\end{array}$ & -72.660 & 14.041 & -5.175 & .000 & .000 \\
\hline $\begin{array}{l}\text { PUBLIC BANK-FOREIGN } \\
\text { VENTURE }\end{array}$ & -87.600 & 14.892 & -5.882 & .000 & .000 \\
\hline $\begin{array}{l}\text { POMESTIC PRIVATE-FOREIGN } \\
\text { VENTURE }\end{array}$ & 14.940 & 11.100 & 1.346 & .178 & .535 \\
\hline
\end{tabular}

Each row tests the null hypothesis that the Sample 1 and Sample 2 distributions are the

same.
Asymptotic significances (2-sided tests) are displayed. The significance level is 05. 